\title{
Exploring the Potential of Calotropis Procera Ait. (Asclepiadaceae) Phytocompounds against S. Aureus TyrRS
}

\section{Beg MA, Qureshi H and Athar F*}

Centre for Interdisciplinary Research in Basic Science, Jamia Millia Islamia, India

*Corresponding author: Dr Fareeda Athar, Associate Professor, Centre for Interdisciplinary Research in Basic Sciences, Jamia Millia Islamia, New Delhi-110025, India, Tel: +91-1126981717 Ext. 4492; Email: fathar@jmi.ac.in

\section{Research Article \\ Volume 5 Issue 3}

Received Date: September 11, 2020

Published Date: September 29, 2020

DOI: $10.23880 /$ oajmb-16000170

\section{Abstract}

In medicinal chemistry the plant-based drugs as an alternative medicine is increasing day by day with realization of toxic effects and health hazards associated with the multiple uses of antibiotics and synthetic drugs and due to the growing resistance of pathogens to conventional antibiotics. Calotropis procera is a tropical plant distributed widely in Asia, Africa, and America and native to north Africa. It can produce a wide range of chemical compounds which are biologically active against multidrug resistance bacterial strains (ESKAPE). In this manuscript the docking analysis find out the antimicrobial potential of these plant-derived compounds against S. aureus tyrosyl-tRNA synthetase (PDB ID: 1JIJ). S. aureus tyrosyl-tRNA synthetase plays an essential role in protein synthesis by producing charged tRNAs. In this screening of docking score 83 phytocompounds selected compounds which has good binding affinity above -10 which Calotroproceryl acetate A (-10.1), L-rhamnose (-10.2) and Lupeol (-10.4). The interacting analysis showing all the three compounds, Lupeol has highest binding energy which has maximum hydrogen bond interaction with CYS37, HIS47, GLY49, HIS50, THR75, GLN174, ASP177 and GLN190. These residues are important for protein activity and therefore binding at these residues may hamper protein's activity all the three compounds interacted with active site residue of $S$. aureus tyrosyl-tRNA synthetase and therefore it is hypothesized that these compounds are the putative target of the protein activity which enhance bacterial pathogenesis and survival.

Keywords: Calotropis procera; Staphylococcus aureus; Tyrosyl-tRNA synthetase; Molecular docking

Abbreviations: C. procera: Calotropis procera; S. aureus: Staphylococcus aureus; TyrRS: Tyrosyl-tRNA synthetase; R05: Lipinski's Rule of Five; 2D: Two-dimensional; 3D: Three-dimensional.

\section{Introduction}

Medicinal plants are the richest source of bioactive phytochemicals which may be responsible for various pharmacological activities including antimicrobial activities [1]. Calotropis procera is an indication that the plant, if properly screened using additional solvents, could yield drugs of pharmaceutical significance and can be used in the traditional medicine system to cure various diseases [2]. The whole plant Calotropis procera was used to treat common diseases such as fever, rheumatism, indigestion, cold, eczema, and diarrhea, for the treatment of boils, to remove thorn from body and for the treatment of jaundice $[3,4]$. The antimicrobial effect of ethanol, aqueous and chloroform extracts of leaf and latex of Calotropis procera on six bacteria ESKAPE pathogens. Herbal medicines may include whole parts of plant or mostly prepared from leaves, roots, bark, seed and flowers of plants. Medicinal plants are the "backbone" of traditional medicine, which means more 


\section{Open Access Journal of Microbiology \& Biotechnology}

than 3.3 billion people in the less developed countries utilize medicinal plants on a regular basis $[5,6]$. C. procera plant is rich source of polyphenolic agents that might be playing an important role in inhibition of progress of several diseases [7]. The above researches provide a support for the use of C. procera in traditional medicine and suggest its further advanced investigation. There is a continuous need of the development of new effective antimicrobial drugs because of the emergence of new infectious diseases and drug resistance $[8,9]$. C. procera was investigated qualitatively and quantitatively by GC-MS. Besides the cardenolides, the other plant-derived given phytochemicals are alkaloids, flavonoids, sterols, saponins, tannins, triterpenes and hydrocarbons coumarins. The reported phytoconstituents contains fatty acids, hydrocarbons, amino acids, proteases, resins and many minerals [10]. The plant is reported for analgesic activity, antimicrobial activity, antioxidant activity, anti-pyretic activity, insecticidal activity, cytotoxicity activity, hepatoprotective activity, pregnancy interceptive properties, purgative properties, procoagulant activity and wound healing activity [11,12]. ESKAPE is an acronym for their names and a reference to their ability to escape the effects of commonly used antibiotics through evolutionarily developed mechanisms [13-17]. Medicinal herbs are more significant to the health of individual and community. In this manuscript author demonstrate the binding form of these compounds in adhesion of the bacterium to the host cell and thus helpful in preventing infection and decreases mortality due to this disease.

\section{Methodology}

\section{Molecular Docking: Ligands Preparation}

The 2D structures of Calotropis procera 83 phytoconstituents were downloaded by PubChem online server which is a freely available. The structures were then converted into Mol 2 format with the help of Chem3D Ultra, and PyRx tool [18].

\section{Target Selection and Preparation}

Earlier reported three-dimensional (3D) structure of the Crystal structure of $S$. aureus TyrRS in complex with SB239629 (PDB ID: 1JIJ) was retrieved from RCSB PDB (https:// www.rcsb.org/structure/1JIJ). The water molecules as well as co-crystallized ligands were deleted from the PDB file [19].

\section{Docking Protocol}

To determine the binding mode and interaction of the selected compounds and target, docking studies were performed using Auto Dock/vina [20,21]. The pdbqt files of the receptor protein, and C. procera compounds along with the grid box getting at the active site of the receptor for compounds binding was done through Auto Dock GUI program. The grid size boundaries along $\mathrm{X}, \mathrm{Y}$, and $\mathrm{Z}$ axes was scaled at $40 \AA$ with a grid spacing of $1 \AA$ to allow proper binding flexibility at the docked site. The output pdbqt files were written into a configuration (conf) file. The receptor was treated rigid entity whereas ligands were kept flexible to attain the best fitting conformation with respect to the receptor complex. The generated solutions of docking were clustered and those with root mean square deviation (RMSD) value $<1.0$ Å were considered only. The binding conformation of ligands with the lowest binding affinity was characterized as the most stable conformation of the ligands with respect to the receptor $[22,23]$.

\section{Physiochemical Properties Studies}

The Physio-chemical properties of the selected compounds were predicted by freely available online Swiss ADME software. In compound analysis R05, the molecular weight (M.W.) is $>500$, number of accepted hydrogen bond ( $\mathrm{O}$ and $\mathrm{N}$ atoms) and number of donor's hydrogen bond ( $\mathrm{NH}$ and $\mathrm{OH}$ ) within Lipinski's limits range from 0-10 (H-bond acceptor) and 0-5 (H-bond donor) respectively. Lipophilicity (log P) and Topological Polar Surface Area (TSPA) values are crucial properties for the forecast of oral liability of drug molecules. The ranging of $\log \mathrm{P}$ from $(0-5)$ our most of the compounds range from 0.94-5.00 $(\leq 5)$, which is the acceptable limits for drug to penetrate bio-membrane [2426].

\section{Receptor-Ligand Interaction Analysis}

The interaction analysis of the protein-ligand and interaction of the binding sites studied by using the PyMOL The possible dock conformations of the 2D ligand-receptor interactions by using Discovery Studio. Further, binding analysis by using visualization approach was carried out to understand the binding pattern of the drug with proteins [27-30].

\section{Results}

\section{Molecular Docking}

Molecular docking was carried out using the using Auto Dock/vina. The grid box getting at the active site of the receptor for compounds binding was done through Auto Dock GUI program. Grids were generated for the prepared proteins. For S.aureus gyrase complex, the grid was generated around SB-239629.

Grid Box Preparation (By using AutoDock Vina). 


\section{Open Access Journal of Microbiology \& Biotechnology}

\begin{tabular}{|c|c|c|c|}
\hline & $\mathbf{X}$ & $\mathbf{Y}$ & $\mathbf{Z}$ \\
\hline Centre of the grid box & -11.179 & 11.702 & 91.461 \\
\hline Dimensions of the grid box & 20 & 22 & 20 \\
\hline
\end{tabular}

Table 1: Grid Box Preparation (By using AutoDock Vina).

The docked PDB ID: 1JIJ bound ligand SB-239629 had docking score $-7.5 \mathrm{kcal} / \mathrm{mol}$. SB-239629 is the (2S)-2[[(2S)-2-Amino-3-(4-hydroxyphenyl)propanoyl]amino]-
$2-[(2 \mathrm{~S}, 3 \mathrm{~S}, 4 \mathrm{~S}, 5 \mathrm{~S})-1,3,4,5$-tetrahydroxy-4(hydroxymethyl) piperidin-2-yl]acetic acid Table 2.

\begin{tabular}{|c|c|c|c|}
\hline S.No. & Compounds & 3D structure & DDG \\
\hline 1 & (6Z), (9 Z) Pentadecadien 1-ol & & -5.8 \\
\hline 2 & (E)-3-(4-methoxyphenyl-2-0-beta & & -6.1 \\
\hline 3 & (E)-Octadec-7-enoic acid & & -5.6 \\
\hline 4 & 1,2-dihexadecanoyl -3-phosphatyl & & -6.3 \\
\hline 5 & 1,3,5-Triisopropylbenzene & & -6.9 \\
\hline 6 & 2,3,4-trimethylhexane & & -4.9 \\
\hline 7 & 2,6 dimethyl tetra-1,5-decaene & & -5.7 \\
\hline 8 & 2-H Benzofuranone 5,6,7, 7A & & -5.4 \\
\hline 9 & 2-limonenyloxybenzoyl- & & -6.4 \\
\hline 10 & 2-propenyl-2-hydroxyethyl & & -5.4 \\
\hline 11 & 3,7,11-Trimethyl-2,6,10,12 & & -6.6 \\
\hline 12 & 3b,27-dihydroxy-urs-18 & & 0.1 \\
\hline 13 & 3b,27-dihydroxy-urs-18-en- & 13 & -1.3 \\
\hline 14 & 4-hydroxy-4-methylpentan-2-one & & -5.0 \\
\hline 15 & 6,10,14-trimethyl, Pentadecanone -2 & & -6.5 \\
\hline 16 & 9,12,15-Octadecatrienoic acid & & -6.2 \\
\hline
\end{tabular}




\section{Open Access Journal of Microbiology \& Biotechnology}

\begin{tabular}{|c|c|c|c|}
\hline 17 & 18 H-urs-12, 2 0(30)-dien-3-yl acetate & & -6.6 \\
\hline 18 & a-amyrin acetate & & -5.8 \\
\hline 19 & a-Amyrin & & -5.5 \\
\hline 20 & Acetic acid & & -3.5 \\
\hline 21 & a-rhamnose & & -6.0 \\
\hline 22 & Benzoylisolineolone & 22 & -3.5 \\
\hline 23 & Benzoyllineolone & 23 & -5.4 \\
\hline 24 & Calactin & & -7.8 \\
\hline 25 & Calotoxin & & -7.8 \\
\hline 26 & Calotropagenin & & -7.1 \\
\hline 27 & Calotropenyl acetate & 27 & -6.6 \\
\hline 28 & Calotropin & & -5.7 \\
\hline 29 & Calotroprocerol-A & & -6.5 \\
\hline 30 & Calotroprocerone-A & & -0.9 \\
\hline 31 & Calotroproceryl acetate A & & -10.0 \\
\hline 32 & Calotropursenyl acetate B & & -4.6 \\
\hline 33 & Cardenolide 2-oxovoruscharin & & -5.9 \\
\hline 34 & Choline & & -5.8 \\
\hline 35 & D-arabinose & $4 x$ & -6.5 \\
\hline 36 & Decane & Mes & -1.8 \\
\hline 37 & Diterpene & Fy & -3.9 \\
\hline
\end{tabular}




\begin{tabular}{|c|c|c|c|}
\hline 38 & Epicatechin & & -5.8 \\
\hline 39 & Ergost-5-en-3-ol & & -4.6 \\
\hline 40 & Farnesol isomer & (12) & -6.6 \\
\hline 41 & Ferulic acid & & -8.1 \\
\hline 42 & Gallic acid & & -7.9 \\
\hline 43 & Glucosamine & & -6.0 \\
\hline 44 & Glucose & & -6.8 \\
\hline 45 & Glyceryl mono-oleolyl-2-phosphate & & -7.3 \\
\hline 46 & Gofruside & & -6.2 \\
\hline 47 & Isorhamnetin-3-0-robinobioside & & -6.5 \\
\hline 48 & Isorhamnetin-3-0-rutinoside & & -7.8 \\
\hline 49 & Isovaleric acid & & -8.8 \\
\hline 50 & L-rhamnose & & -10.2 \\
\hline 51 & Lupeol & & -10.4 \\
\hline 52 & Methyl myrisate & & -4.8 \\
\hline 53 & Multiflorenol & & -6.0 \\
\hline 54 & Naphthalene decahydro2,6 dimethyl & & -6.3 \\
\hline 55 & n-Eicosane & monom & -5.7 \\
\hline 56 & n-Pentadecane & nomon & -1.2 \\
\hline 57 & p-coumaric acid & shes & -5.7 \\
\hline 58 & Proceragenin & weter- & -5.7 \\
\hline 59 & Proceranol n-triacontan-10ß-ol & & -5.0 \\
\hline 60 & Procerasesterterpenoyl & & -6.4 \\
\hline
\end{tabular}




\begin{tabular}{|c|c|c|c|}
\hline 61 & Proceraursenolide & $x+2$ & -6.1 \\
\hline 62 & Proceroside & - & -6.0 \\
\hline 63 & Procerursenyl acetate & & -6.9 \\
\hline 64 & Procesterol & अ & -6.8 \\
\hline 65 & Pseudo-taraxasterol acetate & & -10.0 \\
\hline 66 & Quercetagetin-6-methyl ether & & -8.0 \\
\hline 67 & Quercetin-3 rutinoside & & -7.9 \\
\hline 68 & B-Amyrin acetate & & -4.8 \\
\hline 69 & B-Amyrin & & -8.4 \\
\hline 70 & B-Sitosterol & & -8.7 \\
\hline 71 & Stigmasta-5,22-dien-3-ol & & -7.9 \\
\hline 72 & Stigmasterol & & -8.7 \\
\hline 73 & Syriogenin & & -9.1 \\
\hline 74 & Taraxasterol & & -6.4 \\
\hline 75 & Terpenoid glycosides & & -8.7 \\
\hline 76 & Urosolic acid & & -5.6 \\
\hline 77 & urs-19(29)-en-3-yl acetate & 77 & -6.0 \\
\hline 78 & Uscharidin & & -6.8 \\
\hline 79 & Uscharin & & -4.4 \\
\hline 80 & Uzarigenin & $4 x x^{t a x}$ & -6.2 \\
\hline 81 & Vanillic acid & & -7.0 \\
\hline 82 & Voruscharin a-calotropeol & 82 & -0.4 \\
\hline 83 & Voruscharin & & -2.0 \\
\hline
\end{tabular}

Table 2: Docking score for the phytoconstituents of $C$. procera with PDB ID: 1JIJ. 
In molecular docking the screening of 83 plant-derived compounds produced log files, where the affinity (kcal/ mol) obtained and docked poses for discrete compounds analyzed. This log-file screen-out because of the analysis of binding score or docking score.

\section{Physio-chemical Properties}

The physiochemical analysis and R05 analysis shows that all those compound having >500 MW, >10 number of rotatable bonds (nrotb), number of atoms (natoms), hydrogen bond donor and acceptor $>5$ bonds and $\log P$ value is $>3$ and the parameter of Lipinski's Rule of five unfollow (nVio). Out of these three compounds properties L-rhamnose showing zero nVio which is good for bioavailability of the drug showing in Table 3.

\begin{tabular}{|c|c|c|c|c|c|c|c|c|}
\hline S.No. & MW & miLogP & TPSA & natoms & nON & noHNH & nVio & nrotb \\
\hline Calotroproceryl acetate A & 476.75 & 8.45 & 26.30 & 35 & 2 & 0 & 1 & 2 \\
\hline L-rhamnose & 164.16 & -1.64 & 97.98 & 11 & 5 & 4 & 0 & 4 \\
\hline Lupeol & 426.73 & 8.29 & 20.23 & 31 & 1 & 1 & 1 & 1 \\
\hline
\end{tabular}

Table 3: Physio-chemical parameters of the selected phytocompounds of $C$. procera by using SwissADME.

In this screening of docking score 03 phytocompounds which has good binding affinity above -10 which Calotroproceryl acetate A (-10.1), L-rhamnose (-10.2) and
Lupeol (-10.4). The interaction analysis of PDB ID: 1JIJ complexes are shown in Figure 1.

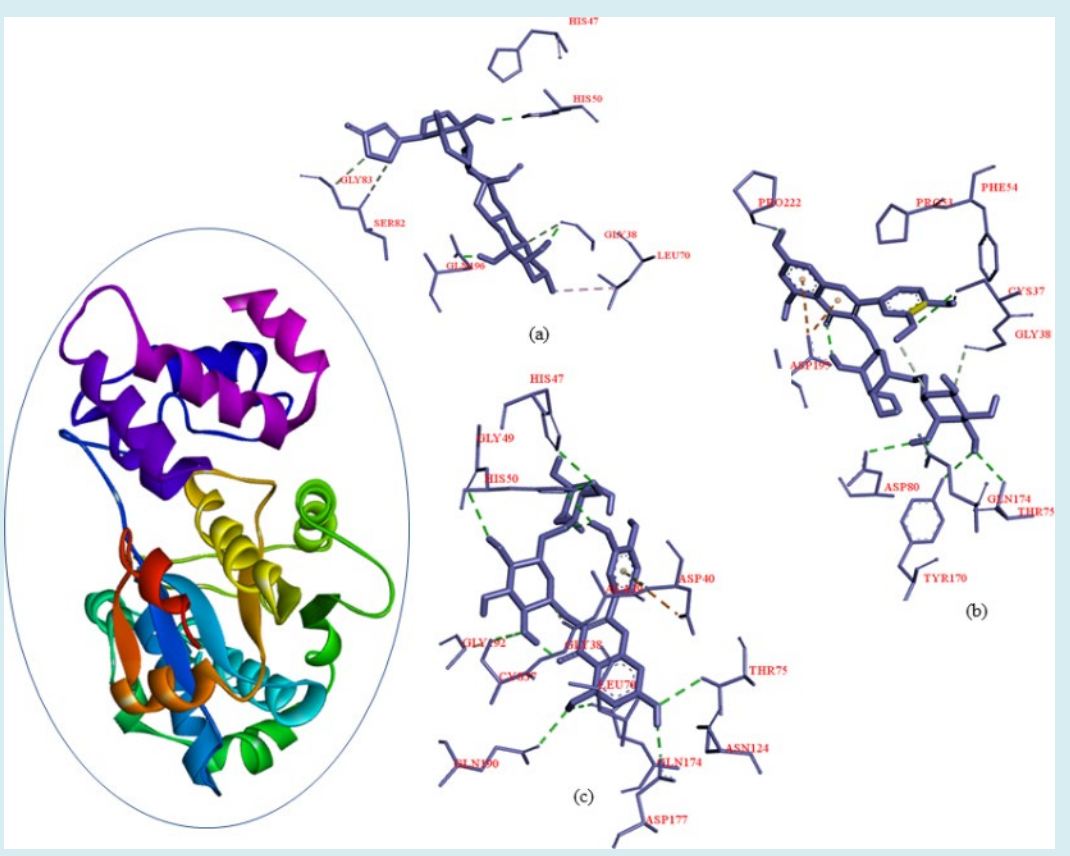

Figure 1: Structure of PDB ID: 1JIJ and the selected top 3 highest biding scores compounds (a-c) Calotroproceryl acetate A, L-rhamnose and Lupeol.

The selected phytocompounds 2D interaction analysis showing involved residues and bonds in Calotroproceryl acetate A, L-rhamnose and Lupeol shows the highly interaction within active site cavity, which is shown in Figures 2-4. 


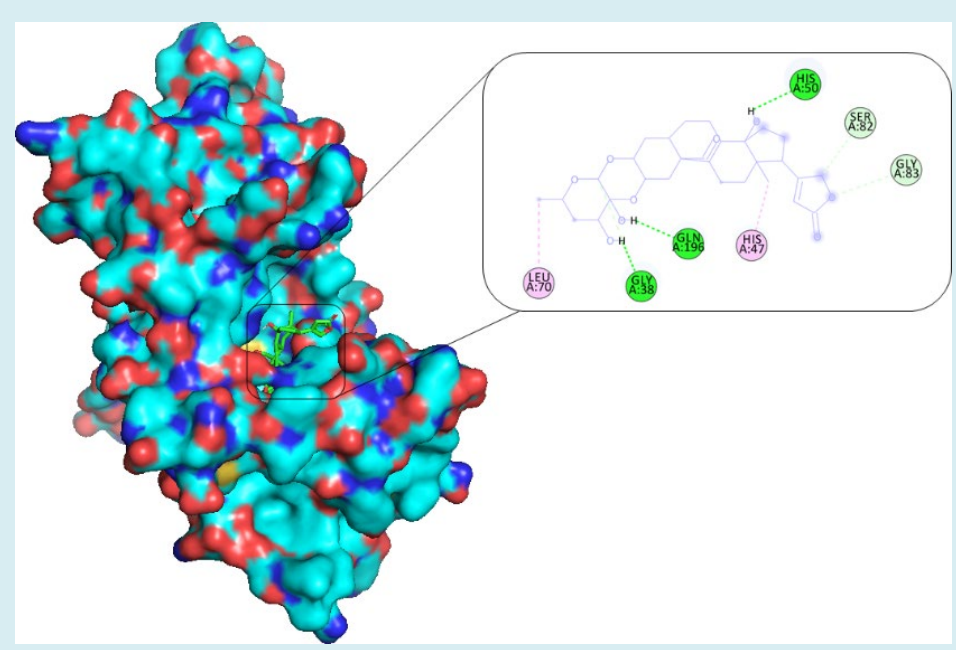

Figure 2: 2D interaction analysis showing involved residues and bonds. The PDB ID: 1JIJ complex with Calotroproceryl acetate A.

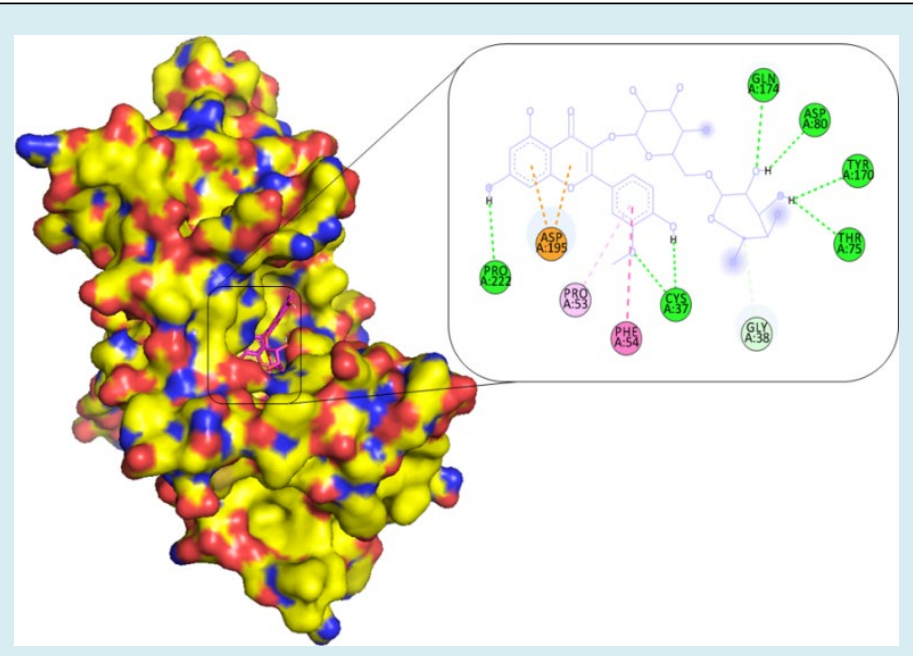

Figure 3: 2D interaction analysis showing involved residues and bonds. The PDB ID: 1JIJ complex with L-rhamnose.

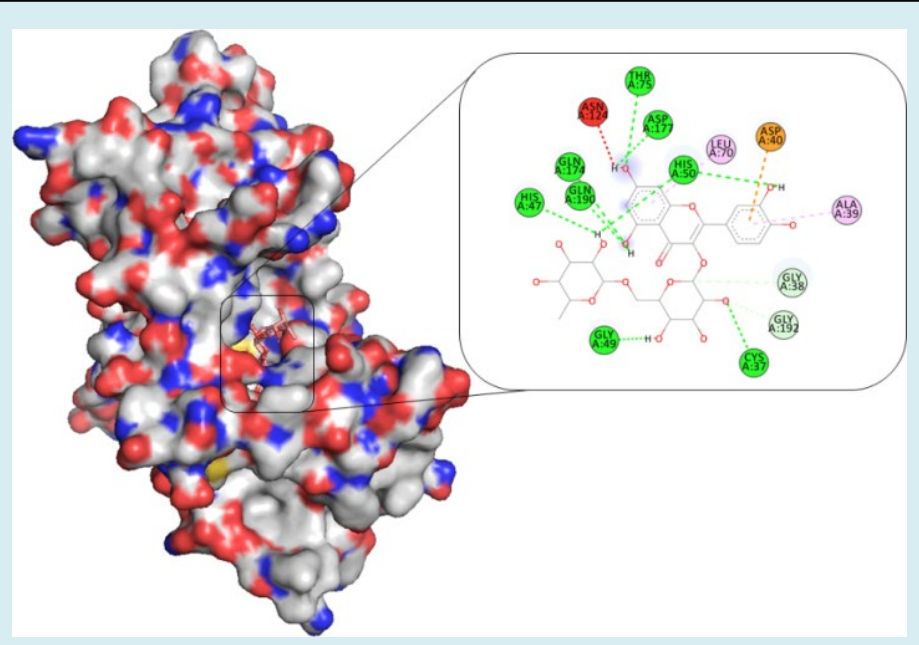

Figure 4: 2D interaction analysis showing involved residues and bonds. The PDB ID: 1JIJ complex with Lupeol. 


\section{Open Access Journal of Microbiology \& Biotechnology}

\section{Receptor-Ligands Interaction Analysis}

The receptor-ligands interaction analysis of $S$. aureus TyrRS ternary complexes with plant-derived compounds as the putative inhibitor. In complex file interaction studies showing all these natural compounds closely interacted with active sites /substrate binding domains. The interaction residues of the ternary structure of $S$. aureus TyrRS protein are Cys37, Gly38, Ala39, Asp40, His47, Gly49, His50, Leu70, Thr75,
Gln174, Asp177, Gln190, Gly192, Asp195 and Pro222. This interaction study confirmed that there was the involvement of Hydrogen bond (H-bond), Carbon-Hydrogen bond (C-H bond) and Pi-Alkyl bond as shown in Table 4. The interaction study showing the strong interaction between $S$. aureus TyrRS protein with natural compounds Lupeol (-10.4) interactions showing the maximum eight hydrogen bond interaction with CYS37, HIS47, GLY49, HIS50, THR75, GLN174, ASP177 and GLN190 residues which are closely interacted in binding cavity.

\begin{tabular}{|c|c|c|c|c|c|}
\hline S.No. & Ligand & $\begin{array}{c}\text { Interacting } \\
\text { Residues } \\
\end{array}$ & Distance $(\AA ̊)$ & Category & Type \\
\hline 1 & Calotroproceryl acetate A & $\begin{array}{c}\text { Gly38 } \\
\text { His47 } \\
\text { His50 } \\
\text { Leu70 } \\
\text { Ser82 } \\
\text { Gly83 } \\
\text { Gln196 } \\
\end{array}$ & $\begin{array}{l}1.58 \\
5.31 \\
1.99 \\
4.09 \\
3.63 \\
3.36 \\
1.83 \\
\end{array}$ & $\begin{array}{c}\text { H-Bond } \\
\text { Pi-Alkyl } \\
\text { H-Bond } \\
\text { Pi-Alkyl } \\
\text { Carbon H-Bond } \\
\text { Carbon H-Bond } \\
\text { H-Bond } \\
\end{array}$ & $\begin{array}{l}\text { Conventional } \\
\text { Hydrophobic } \\
\text { Conventional } \\
\text { Hydrophobic } \\
\text { Conventional } \\
\text { Conventional } \\
\text { Conventional }\end{array}$ \\
\hline 2 & L-rhamnose & $\begin{array}{c}\text { Cys37 } \\
\text { Gly38 } \\
\text { Pro53 } \\
\text { Phe54 } \\
\text { Thr75 } \\
\text { Asp80 } \\
\text { Tyr170 } \\
\text { Gln174 } \\
\text { Asp195 } \\
\text { Pro222 }\end{array}$ & $\begin{array}{l}1.99 \\
3.58 \\
4.13 \\
5.58 \\
2.82 \\
2.67 \\
2.80 \\
2.80 \\
4.52 \\
2.54 \\
\end{array}$ & $\begin{array}{c}\text { H-Bond } \\
\text { Carbon H-Bond } \\
\text { Pi-Alkyl } \\
\text { Pi-Alkyl } \\
\text { H-Bond } \\
\text { H-Bond } \\
\text { H-Bond } \\
\text { H-Bond } \\
\text { Pi-Anion } \\
\text { H-Bond }\end{array}$ & $\begin{array}{l}\text { Conventional } \\
\text { Conventional } \\
\text { Hydrophobic } \\
\text { Hydrophobic } \\
\text { Conventional } \\
\text { Conventional } \\
\text { Conventional } \\
\text { Conventional } \\
\text { Hydrophobic } \\
\text { Conventional }\end{array}$ \\
\hline 3 & Lupeol & $\begin{array}{l}\text { Cys37 } \\
\text { Gly38 } \\
\text { Ala39 } \\
\text { Asp40 } \\
\text { His47 } \\
\text { Gly49 } \\
\text { His50 } \\
\text { Leu70 } \\
\text { Thr75 } \\
\text { Gln174 } \\
\text { Asp177 } \\
\text { Gln190 } \\
\text { Gly192 }\end{array}$ & $\begin{array}{l}3.44 \\
3.72 \\
5.36 \\
4.15 \\
2.79 \\
3.06 \\
2.38 \\
5.41 \\
3.00 \\
2.56 \\
2.10 \\
2.79 \\
3.58\end{array}$ & $\begin{array}{l}\text { H-Bond } \\
\text { H-Bond } \\
\text { Pi-Alkyl } \\
\text { Pi-Anion } \\
\text { H-Bond } \\
\text { H-Bond } \\
\text { H-Bond } \\
\text { Pi-Alkyl } \\
\text { H-Bond } \\
\text { H-Bond } \\
\text { H-Bond } \\
\text { H-Bond } \\
\text { H-Bond }\end{array}$ & $\begin{array}{l}\text { Conventional } \\
\text { Conventional } \\
\text { Hydrophobic } \\
\text { Hydrophobic } \\
\text { Conventional } \\
\text { Conventional } \\
\text { Conventional } \\
\text { Hydrophobic } \\
\text { Conventional } \\
\text { Conventional } \\
\text { Conventional } \\
\text { Conventional } \\
\text { Conventional }\end{array}$ \\
\hline
\end{tabular}

Table 4: Detailed molecular interactions obtained following the rigid ligand docking.

\section{Discussion}

In the present research, we have summarized the current traditional use of medicinal plants Calotropis procera Ait. (Asclepiadaceae) phytocompounds against $S$. aureus TyrRS $[2,4,10-12]$. The data provided here must benefit providing a practical base for further scientific research on these plants and their role in preventing antimicrobial infection [13-15].
Consequently, more plant-derived naturals compounds of C. procera, the docking analysis, the 83 natural compounds against $S$. aureus TyrRS having top three good binding affinity scores compounds above -10 which Calotroproceryl acetate A (-10.1), L-rhamnose (-10.2) and Lupeol (-10.4) [10,18-21]. The physiochemical analysis and R05 analysis shows that all those compound having $>500 \mathrm{MW},>10$ number of rotatable bonds (RB), hydrogen bond donor and acceptor $>5$ bonds and 


\section{Open Access Journal of Microbiology \& Biotechnology}

$\log \mathrm{P}$ value is $>3$ all the properties showing these compounds are good for bioavailability of the drug $[24,25]$. The predicted ligand binding site for $S$. aureus TyrRS protein showing pocket residues 36-54, 70-91, 170-196 and 221-241 [22,23]. The receptor-ligands interaction studies against $S$. aureus TyrRS ternary complexes with natural compounds as the putative inhibitor. In complex file interaction studies showing all these natural compounds closely interacted with active sites /substrate binding domains. The interaction analysis of binding residues of the ternary structure of $S$. aureus TyrRS protein are Cys37, Gly38, Ala39, Asp40, His47, Gly49, His50, Leu70, Thr75, Gln174, Asp177, Gln190, Gly192, Asp195 and Pro222. This interaction study confirmed that there was the involvement of Hydrogen bond (H-bond), Carbon-Hydrogen bond (C-H bond) and Pi-Alkyl bond $[26,27]$. The interaction study showing the strong interaction between $S$. aureus TyrRS protein with compound Lupeol which dock score highest -10.4 and it shows the maximum eight hydrogen bond which is interacted with CYS37, HIS47, GLY49, HIS50, THR75, GLN174, ASP177 and GLN190 residues and all the residues are closely interacted with active sites [28]. The plant-derived compounds of $C$. procera determining the therapeutic target for antimicrobial strains therefore the targeting compounds might be an advantageous step in the direction of therapeutic development.

\section{Conclusion}

In the previous studies the ethno-botanical and traditional uses of C. procera plant-derived natural compounds, have gotten a lot of consideration are notable for their adequacy and are generally believed to be harmless for human use. Using plant-derived compounds is the ancient approach for searching the new target molecules which helps in the medication of the various diseases. In previous studies the review of the published literature on $C$. procera shows these phytoconstituents are in the various remedy of ethnic groups, as well as Ayurvedic and traditional uses. Researchers are exploring the therapeutic potential of this plant as it is likely to have more therapeutic properties than are currently known. C. procera phytocompounds having higher flavonoids content which is involved in antibacterial and antioxidant profiles. Plant-derived compounds of $C$. procera plant showing the antibacterial activity against an ESKAPE pathogenic strains, as well as an interesting antioxidant profile. These phytocompounds could be considered for its antibacterial potential and could be a valuable source for the design and development of new antibacterial compounds. The potential target studies of $C$. procera phytocompounds using molecular docking which helps to find out the best binding pose of the target protein to elucidate a potential mechanism of action for this compound. As further studies, docking with important target PDB ID:1JIJ, tyrosyl-tRNA synthetase from $S$. aureus were studied as potential targets, and a correlation between the observed inhibitory activity and the in silico molecular docking scores was obtained. Moreover, compounds also approved by R05 drug likeness properties. The possible inhibitors of $S$. aureus tyrosyl-tRNA synthetase protein such as L-rhamnose and Lupeol were selected because of high binding affinities and interactions with catalytic triad residues. In vitro work toward this path may give essential information of these proteins that make these proteins magnificent objective for drawing closer for remedial medicine.

\section{References}

1. Cowan MM (1999) Plant products as antimicrobial agents. Clin Microbiol Rev 12(4): 564-582.

2. Hilal-Ul-Zaman, Ahmad S (2017) Antibacterial Activity and Phytochemical Analysis of Leaf Extracts of Calotropis procera. Acta Scientific Pharmaceutical Sciences 1(5): 19-21.

3. Al-Snafi AE (2013) Encyc lopedia of the constituents and pharmacological effects of Iraqi medicinal plants. Thi qar University.

4. Al-Snafi AE (2015) The constituents and pharmacological properties of Calotropis procera-An Overview. International J Phar Rev Res 5(3): 259-75.

5. Mata R, Figueroa M, Navarrete A, Rivero-Cruz I (2019) Chemistry and Biology of Selected Mexican Medicinal Plants. Prog Chem Org Nat Prod 108: 1-142.

6. Ahvazi M, Khalighi-Sigaroodi F, Charkhchiyan MM, Mojab F, Mozaffarian VA, et al. (2012) Introduction of medicinal plants species with the most traditional usage in Alamut region. Iran J Pharm Res 11(1): 185-194.

7. Sameeh MY, Mohamed AA (2018) Characterization of polyphenols by HPLC, their antioxidant and GC-MS analysis of wild Calotropis procera leaves and fruit extracts. Int J ChemTech Res 11(1): 319-327.

8. Shami AM, Philip K, Muniandy S (2013) Synergy of antibacterial and antioxidant activities from crude extracts and peptides of selected plant mixture. BMC Complement Altern Med 13: 360.

9. Kar D, Patnaik PK, Patnaik B, Kuanar A (2018) Antimicrobial analysis of different parts extract in different solvent system of a waste weed-Calotropis procera. Asian J Pharm Clin Res 11(2): 227-30.

10. Parihar G, Balekar N (2016) Calotropis procera: A phytochemical and pharmacological review. TJPS 40 (3): 115-131.

11. Chandrawat P, Sharma RA (2015) GC-MS Analysis of 


\section{Open Access Journal of Microbiology \& Biotechnology}

fruits of Calotropis procera: A medicinal shrub. Res J Recent Sci 4: 11-14.

12. Rahimi M (2015) Pharmacognostical Aspects and Pharmacological activities of Calotropis procera. Bull Env Pharmacol Life Sci 4(2): 156-162.

13. Chambers HF, Deleo FR (2009) Waves of resistance: Staphylococcus aureus in the antibiotic era. Nat Rev Microbiol 7(9):629-641.

14. Elsner HA, Sobottka I, Mack D, Claussen M, Laufs R, et al. (2000) Virulence factors of Enterococcus faecalis and Enterococcus faecium blood culture isolates. Eur J Clin Microbiol Infect Dis 19(1): 39-42.

15. Houang ET, Sormunen RT, Lai L, Chan CY, Leong AS (1998) Effect of desiccation on the ultrastructural appearances of Acinetobacter baumannii and Acinetobacter lwoffii. J Clin Pathol 51(10): 786-788.

16. Høiby N, Bjarnsholt T, Givskov M, Molin S, Ciofu 0 (2010) Antibiotic resistance of bacterial biofilms. Int J Antimicrob Agents 35(4): 322-332.

17. Kumarasamy KK, Toleman MA, Walsh TR, Bagaria J, Butt F, et al. (2010) Emergence of a new antibiotic resistance mechanism in India, Pakistan, and the UK: a molecular, biological, and epidemiological study. Lancet Infect Dis 10(9): 597-602.

18. Beg MA, Athar F (2020) Pharmacokinetic and molecular docking studies of Achyranthes aspera phytocompounds to exploring potential anti-tuberculosis activity. J Bacteriol Mycol Open Access 8(1): 18-27.

19. Beg MA, Thakur SC, Athar F (2020) Molecular modeling and in silico characterization of mycobacterial Rv3101c and Rv3102c proteins: prerequisite molecular target in cell division. Pharm Pharmacol Int J 8(4): 234-243.

20. Trott 0, Olson AJ (2010) AutoDock Vina: improving the speed and accuracy of docking with a new scoring function, efficient optimization, and multithreading. J Comput Chem 31(2):455-461.
21. Dallakyan S, Olson AJ (2015) Small-molecule library screening by docking with PyRx. Methods Mol Biol 1263: 243-250.

22. Beg MA, Thakur SC, Athar F (2020) Computational annotations of mycobacterial Rv3632 that confers its efficient function in cell wall biogenesis. J Bacteriol Mycol Open Access 8(2): 46-53.

23. Tian W, Chen C, Lei X, Zhao J, Liang J (2018) CASTp 3.0: computed atlas of surface topography of proteins. Nucleic Acids Res 46(W1): W363-W367.

24. Daina A, Michielin O, Zoete V (2017) SwissADME: a free web tool to evaluate pharmacokinetics, druglikeness and medicinal chemistry friendliness of small molecules. Sci Rep 7: 42717.

25. Beg MA, Athar F (2020) Computational method in COVID-19: Revelation of Preliminary mutations of RdRp of SARS CoV-2 that build new horizons for therapeutic development. J Hum Virol Retrovirolog 8(3): 62-72.

26. Beg MA, Athar F (2020) Anti-HIV and Anti-HCV drugs are the putative inhibitors of RNA-dependent-RNA polymerase activity of NSP12 of the SARS CoV- 2 (COVID-19). Pharm Pharmacol Int J 8(3): 163-172.

27. Rigsby RE, Parker AB (2016) Using the PyMOL application to reinforce visual understanding of protein structure. Biochem Mol Biol Educ 44(5): 433-437.

28. Biovia DS (2015) Discovery studio modeling environment. Dassault Systems, San Diego.

29. Beg MA, Shivangi, Thakur SC, Meena LS (2018) Structural Prediction and Mutational Analysis of Rv3906c Gene of Mycobacterium tuberculosis $\mathrm{H}_{37} \mathrm{Rv}$ to Determine Its Essentiality in Survival. Adv Bioinformatics 2018: 6152014.

30. Beg MA, Shivangi, Fareeda A, Meena LS (2018) Structural And Functional Annotation of Rv1514c Gene of Mycobacterium tuberculosis $\mathrm{H}_{37} \mathrm{Rv}$ As Glycosyl Transferases. J Adv Res Biotech 3(2): 1-9. 